\title{
Decoding and deterritorialization. Capitalism and state in the thought of Gilles Deleuze and Félix Guattari
}

Keywords: Deleuze, Guattari, capitalism, state, deterritorialization, decoding, machines, devices, postmodernism, poststructuralism, rhizome

\begin{abstract}
This text aims to present the thoughts of Gilles Deleuze and Félix Guattari in the context of the relationship between the state, capitalism, and machines. Due to the multiplicity and rhizomatics that characterize the works of both French philosophers, the author also outlines the basic concepts important from the point of view of the discussed problem, such as abstract machines, devices, segmentation, deterritorialization, coding, axiomatics, rhizoma, micropolitics, and macropolitics. The perspective proposed in the works of Deleuze and Guattari escapes the well-known patterns of analysis in social sciences, which makes them an interesting look at the relationship between the state and capitalism.
\end{abstract}

The French philosopher Michel Foucault exerted a huge influence on social sciences by presenting the advantages of poststructuralism in his research. Firstly, he contributed to a change in perceiving the phenomena of power - the latter was not any more present only through hierarchical lines but it functioned in each social relation and, what is

* ORCID ID: https://orcid.org/0000-0001-7963-2948; doctoral candidate at the Department of Political Science and International Studies at the University of Warsaw. His research interests include the theory of politics, the philosophy of politics and the history of political thought with a special emphasis on critical theories, philosophical hermeneutics as well as the relations between technology and society. Email: piotr_rutkowski@uw.edu.pl 
more, it created them on the level of preconditioning 1 . Secondly, he showed that the reality surrounding us is not objective but it is continually entangled in the systems of power - that which is beyond the eye of a human being, which is hidden and unknown. No concepts or their content are a reflection of the surroundings as they hide an axiological load, they are a reflection of the "spirit of time" by means of which man is to receive, project the world and act in a definite manner ${ }^{2}$. These considerations sparked off discussions around the concepts and approaches within social sciences.

In Foucault's shadow, especially in the perspective of political sciences, another post-structuralist - Gilles Deleuze, who cooperated with the author of The Archeology of Knowledge and after his death continued Foucault's work in a creative and original way, wrote his works ${ }^{3}$. His reflections show an interesting perspective of the phenomena of power or state which escape the classical patterns of political sciences, or social sciences in general. The reason for the little popularity of this author in political sciences might be the eruditeness of his considerations, a lack of order in them, a seeming incoherence of the content and far reaching digressiveness. Texts by postmodernists, post-structuralists are usually characterized by problems (in decoding) connected with the aforementioned elements, including an original terminological network ${ }^{4}$. However, here lies a paradox - a seeming incoherence becomes a coherence when looked at more closely. The basic question is as follows: how to describe the understanding of the problem departing from the traditional model of science, evading schemes, networks and methods enforced by the repressive system the aim of which is to walk away from the thoughts, capture individuality, originality and full subordination? Deleuze and Guattari outline a vision of two sciences: royal science based on general regularities measured empirically, and nomadic science, which is insightful and which searches for peculiarities, for understanding and which resembles wandering ${ }^{5}$. The other of the aforementioned ones moves away from the enforced model of science, book or another scientific work - it is the one

1 Cf. M. Foucault, On Power, [in:] M. Foucault, Politics, Philosophy, Culture and Other Writings, New York 1990; J. Scott, Wtadza, Warszawa 2006, pp. 17-20, 116-137.

2 Cf. M. Foucault, Archeologia wiedzy, Warszawa 1977; M. Foucault, Nadzorować i karać. Narodziny więzienia, Warszawa 1998; M. Foucault, Historia seksualności, Warszawa 1995.

3 Cf. G. Deleuze, Michel Foucault's Main Concepts, [in:] G. Deleuze, Two Regimes of Madness. Texts and Interviews 1975-1995, Massachusets 2006.

4 Cf. P. Rutkowski, Bernard Stiegler, Taking Care of Youths and the Generations, [in:] P. Rutkowski, J. Ziółkowski (eds.), Oblicza przemocy, Warszawa 2019.

5 G. Deleuze, F. Guatarri, Tysiąc Plateau, Warszawa 2015, pp. 443-460. 
represented by Deleuze, the one in the form of a rhizome (discussed later on). And here coherence is shown - the perspective of a nomadic science requires a presentation of problems in a different way, a search for other concepts, maybe unclear and blurred, but thanks to this creative, open to interpretation, inspiration and continuation.

The purpose of the text is to present the thought of Deleuze and Guattari in the context of the capitalist state and the relations between capitalism and state. The "bottom up", individual and social, aspect will be a special object of interest, which means the creation of a social formation, repression, a desire for subordination, subjugation, the creation of an individual and broader wholes, which issues are largely according to the assumptions of the critical theory ${ }^{6}$. Realization of this goal, however, will require certain intermediary steps. In connection with the above reflections on conceptual difficulties it will be necessary to present, or rather interpret a few issues proposed by Deleuze and Guattari.

Each analysis of a scientific problem is interpretation. The situation is not different in this case, especially that the subject is the political thought. Here, however, interpretation acquires an additional dimension. This interpretation is conducted on a text open to meaning. Such are the works by Gilles Deleuze and Félix Guattari. Each successive study can bring similar conclusions or different ones, close or divergent ones. It is the same with each work of a post-modernist. What is more, this is taught by philosophical hermeneutics of Hans-Georg Gadamer with which the author of the present text identifies. In the light of this perspective, understanding is something more than interpretation; it means becoming conscious of one's own pre-judgements (culture, tradition, language, experience or one's own knowledge), a self-reflection aimed to reveal them (in the sense that in research they should not perform a concealed role, as if beyond the subject) and full openness onto the Other, onto the object which is surrounded by reflection. This does not exclude the participation of subjectivity but it is accepted as inevitable ${ }^{7}$. What are political sciences if not phronesis, assuming the participation of individuality, context entangled in meanings 8 ? Capitalism and a capitalist

6 Cf. A. Szahaj, Teoria krytyczna szkoty frankfurckiej. Wprowadzenie, Warszawa 2008.

7 P. Rutkowski, Hermeneutyka filozoficzna wobec wybranych problemów metateoretycznych, [in:] F. Pierzchalski, M. Tobiasz, J. Ziółkowski (eds.), Podmiot - kultura - socjotechnika. Wokót holistycznej interpretacji polityki. Ksiega jubileuszowa dedykowana profesorowi zw. dr. hab. Mirosławowi Karwatowi, Warszawa 2020.

8 Cf. D. Teichert, Hermeneutics: Polity, Politics, and Political Theory in Gadamer's Philosophical Hermeneutics, «Teoria Polityki» 2020, No. 4. 
state are - because of the market - universal problems but in the cultural sense they do not touch all societies in the same degree. Reterritorialization (its essence will be explained in the further parts of the present text) seems to be easier where tradition, religion and culture play a decreasing role and the economic criteria used absolutely come to the fore.

\section{Rhizoma, micropolitics and macropolitics}

At each stage of life man strives at setting in order the world which surrounds them, not only in the technical but also the cognitive sense. A special roles is played by science, one of the tasks of which is to broaden the knowledge and understanding of the world - society, nature or the human being themselves. Deleuze and Guattari call this tendency to set in order and search for certainty using the name of trees or rootlets. They have one main, central part which develops into other smaller ones. This is a picture of the hierarchical system which possesses the superior unity around which its particular elements are organized. To function, they must depart from the trunk, otherwise they die out. This is not only a reflection of a human tendency to certainty and to ordering the world but also the way of perceiving the reality itself. A question, however, appears: is the world really ordered? Is the reality which science attempts to conceive structuralized or vague, full of complications, twists and blurred, hidden and unrecognizable aspects? "The tree tires us, we will not believe in trees, in roots and rootlets. The whole tree culture is based on them (...). The thought is not tree-like (...)"9. In opposition to the above there are rhizoma - accentric, complicated, vague and twisted systems. As a result of rhisomaticity a counter-thought is formed which is not subjected to the thinking imposed by the state or system; it brings down its walls, escapes repression and makes it impossible to become a copy ${ }^{10}$. And then nothing is permanent, clear or ordered. The reality is a tangle of lines like rhizoma. Searching for permanence makes the essence and sense of phenomena more distant. This should not only be a vision of the surrounding world but also a way of perceiving it.

Deleuze and Guattari distingush the following properties of the rhizome $^{11}$ :

9 G. Deleuze, F. Guattari, Tysiac..., p. 17.

10 Cf. Ibidem, pp. 461-467.

11 Cf. Ibidem, pp. 7-17. 
- connection - in case of a tree there is one central point which connects everything. In case of rhizome each element can be connected with each in any place and they will continue functioning together, lasting and developing;

- heterogeneity - the connected elements do not have to come from one, they can derive from many different places, dimensions or aspects;

- multiplicity - rhizomes cannot be brought down to unity, there is no hierarchy in it and everything functions "beside";

- asignifying rupture - breaking the line of a rhizome does not mean its destruction as it continues to grow in another direction and it lasts. In centric systems the destruction of the center seems to be the end for the whole while here it is the opposite. Power is an example - in the hierarchical view of society it is power which is conceived to be the central, ordering element which manages others and from which others grow. In the light of rhizomatics the removal of power does not mean the end but just another stage following the former. Such a situation opens up new processes and society as a line (additionally, not a straight line but a zigzag one) follows in another direction;

- cartography and decalcomania - it is not so much a feature but a principle. Hierarchical systems are reproducing all the time, creating tracings and closing to reproduction of what already exists. Will a tracing always be identical? It will try to imitate, while a map is open, it has a number of lines and roads and it can be modified. In other words, a map releases creativity, it allows following a lot of lines while a tracing keeps man within what already exists and it gets subordinated to what is given.

Summing up, in reality, including the social reality, we should not look for constant footholds, for constancy, universalism or rules but peculiarities. Phenomena are complicated entities which depend on a number of factors. Neither them nor their aspects and dimensions are static, they are changing all the time and they undergo various processes from different directions. They constitute a multiplicity - processes comprise other processes and the following contain phenomena which function in the conditions of continuous modifications. Therefore, the world is a picture created by free movements of the brush, from a distance, with closed eyes and with many colours. Deleuze and Guattari suggest seeing and understanding it in this way. 
The features of the rhizome are transferred onto the social world. Micropolitics, macropolitics, the molar and the molecular ${ }^{12}$. It would seem that these are the terms trying to distinguish the isolated levels of analysis organizing the research and similar to those used in political sciences - micro, mezzo and macro. In this case Deleuze and Guattari do not follow this way. As indicated above, reality is undefined. Micro and macro mingle with each other all the time. Is either one of them more significant than the other? Definitely no. Does macropolitics have a bigger influence on reality than micropolitics and is it more significant? This cannot be stated. Deleuze and Guattari do not define those concepts directly. Nevertheless, they propose an example. Fascism was not a top-down idea of establishing such a state. Its organization on the molar level or on the level of macropolitics was possible only through a strong background in the molecular or micropolitical spheres. The society itself desired repressions which occurred. "But fascism is inseparably connected with molecular centres which are multiplied and jump from one point onto another, affecting each other in this way (...). Rural fascism and the fascism of the city, or the district, youth fascism and the fascism of combatants, fascism of the left and of the right, of a couple, school or office: each fascism is defined by a micro-black whole which has a value in itself and in connection with others before it starts to covibrate in the huge central, generalized black whole"13.

Therefore, it is worth to consider micro- and macropolitics in the context of another problem. National identity or the concept of nation generally seems an interesting problem. The state, family and other entities create cultural content passed on to successive generations (macropolitics, molar); however, when it has no bearing in each "micro-tissue", inside the society (micropolitics, molecular) it could lead to undermining, and even in case of resistance on the part of the majority, to blowing up from inside. It is for this reason the systems aim at integration and coherence so that no opposition will be born inside them and their basis will not be undermined ${ }^{14}$. Hence, two relations of proportionality are possible between the molecular and the molar:

12 Molar and molecular are the concepts used by Deleuze and Guattari to indicate what is social, or it concerns large groups and states, as well as what is singular (individual and collective).

13 G. Deleuze, F. Guattari, Tysiąc..., p. 257.

14 Cf. T. Sasińska-Klas, Socjalizacja polityczna. Teorie, badania, ustalenia, Kraków 1992; R. Dahl, B. Stinebrickner, Wspótczesna analiza polityczna, Warszawa 2007, pp. 51-54; B. Kaczmarek, Organizacje: polityka, władza, struktury, Warszawa 2001, pp. 46-53; J. Szacki, Historia myśli socjologicznej, Warszawa 2002, pp. 819-822. 
- directly proportional - the stronger the molar organization, with the more considerable power its influences spread out onto the molecular and the more present they are in the micro-tissue. Then they support each other. For example, a state's repression on the cultural background which finds support in society (in each of its fragments) through the effect on the basis of preconditioning.

- inversely proportional - what is molecular does not support what is molar thus putting a dam, and it can aim at change, e.g. revolutions or cultural changes.

Therefore, what is molecular comes down to what is molar, and vice versa. It deserves to be remembered that politics is not an objective activity; these are above all the relations between the people rooted in culture $^{15}$. What happens in macropolitics has its basis in micropolitics, in the molecular (e.g. in culture itself, in an individual's experiences or, generally, in the cognitive aspect - notions, metaphors, etc.)

Of what importance are the above reflections for capitalism and state? Putting these issues together gives rise to a suspicion that they should be analyzed from the traditionally viewed level of macro. What appears directly might be illusory (after all, Heidegger warned about $\left.{ }^{i 1}{ }^{16}\right)$. Deleuze and Guattari teach that the mechanisms of repression and subordination should be sought elsewhere, in what is unclear and indefinite. What seems to have its essence only on the level of macro might be hidden in social formations, in man, and function there and affect the course of processes. Might it be that what is molar is the effect of the molecular action? In other words, connecting the state with capitalism and its consequences might be a top-down activity permeating each element of the social tissue, or the other way round (like in case of the aforementioned micro-fascisms) it finds its enormous support or resistance in what is molecular.

\section{Social formations and machines}

Before we move on to the presentation of the kinds of social formation which Deleuze and Guattari distinguish in their works, it is necessary to present a few concepts which make it possible to understand and follow the reflections of the French philosophers.

\footnotetext{
15 Cf. A. Laska, O niezbędności politologicznej interpretacji - subiektywność i narracyjność jako determinanty warsztatu politologa, «Teoria Polityki» 2020, No. 4.

16 Cf. M. Heidegger, Bycie i czas, Warszawa 2013, pp. 34-48.
} 
Michel Foucault wrote about devices, diagrams, abstract principles which form societies (for this reason, for example, this philosopher proposed the concept of disciplinary societies), while Deleuze and Guattari suggest a number of concepts referring to the production of societies, which is presented in diagram 1 in a certain simplified manner. It should be remarked that successive elements do not mean the hierarchy or the level of subordination but the degree of abstractedness of a given concept in relation to social reality and social formations.

\section{Diagram 1. The production of societies according to Deleuze and Guattari}

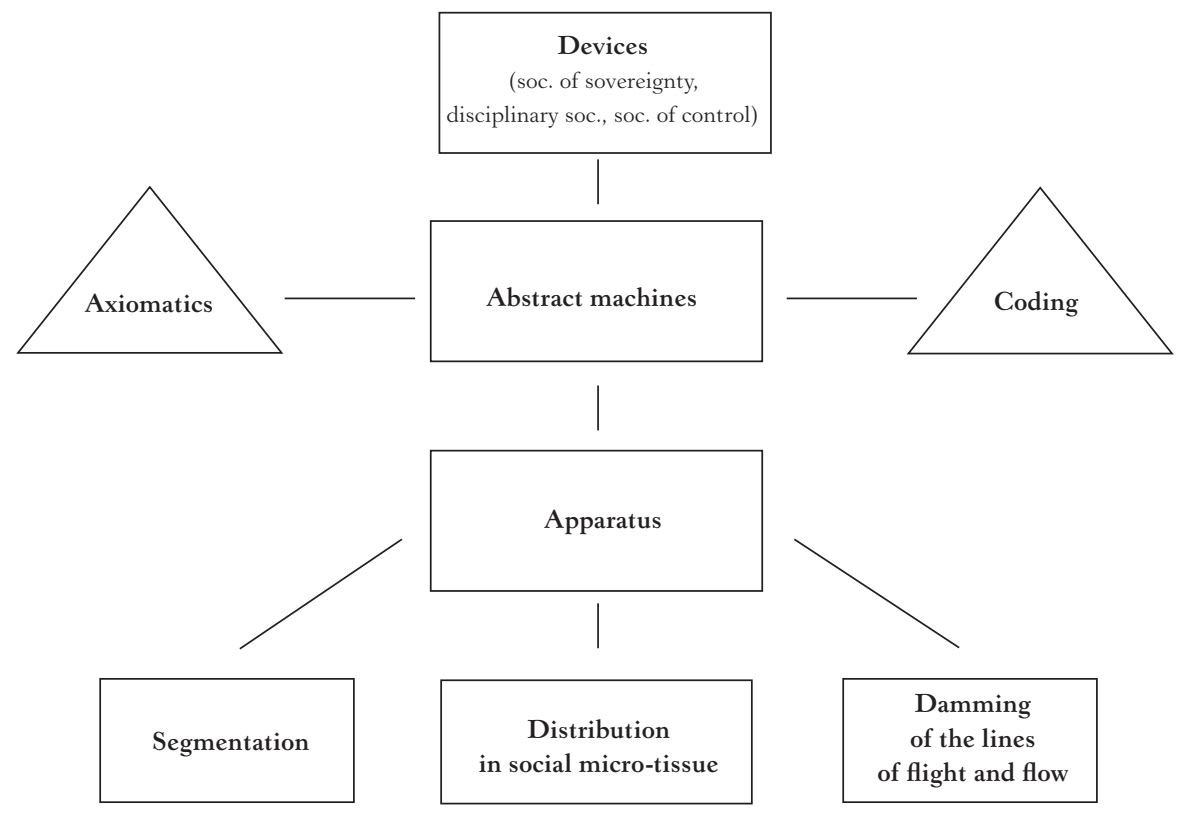

Source: author's own study.

Due to the abstract character of the concept "device", the latter is extremely difficult to define. However, it can be viewed in such a way that it is everything which defines our reality at a given historical moment as well as all past forms of rationality. It is a network of relations between the elements which predetermine man and create their world ${ }^{17}$. They are present in each situation - "We belong to these apparatuses and

17 Cf. M. Nowicka, 'Urzadzenie', 'zastosowanie', 'uktad' - kategoria dispositif u Michela Foucaulta, jej thumaczenia i ich implikacje dla postfoucaultowskich analiz władzy, «Przegląd Socjologii Jakościowej» 2011, No. 2. 
act in them"18. In everything and in nothing at the same time, in what is discursive an non-discursive. Deleuze points out that each device is directed by its rationality and irrationality, it assigns something as the truth, good and hence they cannot be perceived as universal - each type of device produces concepts and criteria which are built in in reality.

Therefore, all theses about one reason enabling the assessment of all the world and about universals should be rejected. Things should be above all perceived in their immanence. "Unity, Whole, Truth, object, subject are not universals but peculiar processes of unification, totalization, verification, objectivization and subjectivization immanent to a device. Each device then is a multiplicity within which definite processes of becoming occur which are different from those taking place in other devices" 19 .

The concept of machine usually refers to the whole process of production, which starts with setting in motion. The result of this activity is a product. This intuition does not fail in case of Deleuze's proposition. It accounts not so much for abstract principles (like in case of devices) but a concrete organization of this reality, its production and building up the whole in man. It sees to it that everything which happens within it is captured and subordinated to its rules. It guards so that nothing can escape or put up resistance to the whole system - "(...) it organizes the dominant utterances and the established order of a society, the dominant language and knowledge, conformist actions and feelings, the segments which prevail over the others" 20 . In this respect it makes use of codes or directly axiomatics. In case of the latter they concern abstract, blurred elements and relations which are directly used to all domains. In case of Deleuze and Guattari's thought, axiomatics are above all the elements connected with capitalism - capital, interest, market rules. Codes, on the other hand, concern each domain separately and they express relations between some elements. These are first of all the contents following from culture, which establishes certain relations in each domain (e.g. the way of contracting marriages, rituals or - as it can b seen in the further parts of the present text - attachment to the land or the state). The success of the machines' activity is guarded by the apparatus in the form of state (then it is an abstract machine of overcoding) or a community

\footnotetext{
18 G. Deleuze, What is a Dispositif?, [in:] G. Deleuze, Two Regimes..., p. 345. Depending on the translation, the French word "Dispositiff" is translated as "device" or "apparatus" (as it is present in the quote). Due to clarity of considerations the term device is preferred and used.

19 Ibidem, p. 342.

20 G. Deleuze, Many Politics, [in:] G. Deleuze, Dialogues, New York 1997, p. 129.
} 
as its direct models of realization. The effectiveness of machines on the social field depends on it. They establish social subjection, which means a situation when "man is placed as the object which refers to the externalized object, (...) man, therefore, is not any more an element of the machine but a worker, a user... (...)"21. Individuals are then harnessed in the whole of the system and they occur both as the object and subject of repression, symbolic violence. Apparatuses are composed of centers of power which affect in three spheres:

- they perform segmentation, closing individualities within the frames proper for machines;

- they spread out onto what is molecular - so they are present everywhere: in individuals, small and big groups, in the whole society;

- when segmentation is not possible (impotence occurs), they undertake attempts to dam the line of flight, which means those that give birth to resistance, which are cracks in the system that can burst and give birth to individuals who are critically inclined towards the system.

Two more remarks are necessary. In Deleuze and Guattari's concept man is composed of different kinds of lines: rigid segmentation, their flexible variations and the lines of "velocity" and "flight". The first refer to the simplest, frequently binary elements of who man is - man-woman, child-adult, school-army-factory, etc. the next ones are more flexible because they are specification and modification of the stiff ones, which means that in the army one can be the general, a private, while within a profession - a teacher, a doctor. The third type, on the other hand, concerns the sphere of individuality and desire. In Anti-Oedipus, Deleuze and Guattari present the concept of productive unconsciousness oriented towards the production of desire, flows, which are emanations of human "I" disjoined from the social field, from what the state apparatus and the machines enforce ${ }^{22}$. At this stage already the apparatus enforces segmentation, which means that it engages the flow into the order established by the machine and produces a desire of repression. Segmentation itself takes place, however, at each stage of an individual's life so that their desire will not change into resistance towards what is social.

Deleuze and Guattari show various social formations occurring in the course of history. A fairly significant remark should be made here. These philosophers reject evolutionism, which quite frequently occurs when different kinds of societies or communities are described. All social

21 G. Deleuze, F. Guattari, Tysiac..., p. 565.

22 Cf. G. Deleuze, F. Guattari, Anty-Edyp. Kapitalizm i schizofrenia, Warszawa 2017, pp. 7-57. 
formations co-occurred in the course of history, they entered into continuous relations, resisted each other, etc. It is the same with states and nomads, with primitive communities and capitalism - they do not come from different periods, they do not follow each other in a straight line of passage or progress. "However, it is impossible to derive the thesis of evolution from here, even zigzagging from primitive peoples to states and from states to nomadic war machine: or at least the zigzag does not mark the consequences but it runs through the places of topology defining primitive societies here, states there, and war machines elsewhere. (...) Communities can be migratory, semi-settled or nomadic, which does not mean that they constitute preparatory stages of the state which is already there or which is elsewhere or somewhere aside" 23.

The first of the enumerated machines which produce a concrete type of group in the social field is a territorial machine. Its object are primitive communities or rural communities characterized by attachment to the land. Segmentation is based on small local groups, which are either attached to a specific place or they mark themselves through a system of lineage and alliances (clan, tribal systems). Significantly, coding - so in a certain sense also each individual's identity - and communities are based on the aforementioned elements, with the special role of territory. Deleuze and Guattari point out that the territorial machine repelled, through which it sensed the coming of other methods of coding with which it co-existed. Through constant uncertainty and dispersion of power into chiefs or leaders of many groups it escaped the coming of the state and - through other forms of exchange and values (marriages, rituals, prestige) - it removed from itself the decoding power of capitalism ${ }^{24}$.

The barbarian despotic or imperial machine is, however, coming with an enormous force, breaking some of the earlier coding and establishing its own. There appears a state with its apparatus and bureaucracy. However, the previous codes and segments are not completely destroyed but they become the functional part of a new social formation. In other words, the attachment to territorial communities, identification with them, clan and tribal systems do not undergo changes. Nevertheless, "a new covenant" is established which places a new state and a new despot at their head. An additional level of code is established which overwrites itself over the territorial one as a result of overcoding - abstract and state one and each of the (territorial) parts has to integrate around it.

23 G. Deleuze, F. Guattari, Tysiac..., pp. 531-532.

24 Cf. G. Deleuze, F. Guattari, Anty-Edyp..., pp. 172-173. 
A mechanical connection of territoriality with abstract statehood will be ruined in the form of Urstaat. It can be stated that it transfers the overcoding of the despotic machine onto the spiritual level - it establishes completely new codes, it does not aim at consolidating territoriality but creates a whole from anew. Therefore, the territorial connection of people and the origin gets completely destroyed and replaced by the next stage of attachment to a completely abstract being - the state. In this moment other forms of segmentation also appear - not the clan, not the tribe but classes.

\section{State and capitalism}

The aforementioned despotic machines and Urstaat began the processes of overcoding and deterritorialization. This means that they either built up their codes over the existing ones or they replaced them through the reference to abstract objects, thus tearing them away from the original codes and made the object - land increasingly unreal. The whole process is ended with capitalism, which is a full movement of deterritorialization and which establishes axiomatics of decoded flows. It is not that the state itself (which established its codes earlier) did not repel capitalism. Any attempt to regulate trade, market etc. was an anticipatory activity (e.g. when the monopoly for trade was possessed only by the state) just like the communities produced within the territorial machine repelled the coming of the state by dispersing the power. Towns, however, increasingly contributed to decoding in their activity of repelling the state. "This very process [autonomization through towns and trade associations - P.R.] gives birth to towns, which are no longer in any relation to their proper land since they ensure trade between empires or - even better - they themselves create a free trade network with other towns. (...) can it not be said that capitalism is the fruit of towns and it is born when the urban recoding gradually replaces the state overcoding?" 25 . The above factors made the state lose control over capital, by which it became an object and the capitalist machine freed itself from the state's control and established axiomatics of decoded flows based on the world, universal market ${ }^{26}$.

25 G. Deleuze, F. Guattari, Tysiac..., p. 536.

26 Cf. P. Rutkowski, Homo Cōnsūmēns. Kulturowy model człowieka w epoce zglobalizowanego kapitalizmu kognitywnego, «Annales Universitatis Paedagogicae Cracoviensis. Studia Politologica» 2019, No. 22. Cf. B. Stiegler, Taking Care of Youth and the Generations, Stanford 2010. 
How does, however, capitalist deterritorialization differ from state deterritorialization? The despotic machine left the codes produced by the territorial machine, building them up, Urstaat replaced them with its own, more abstract ones, while capitalism refers to axiomatics, which is found on possibly the highest level of abstraction, to the category of the market, viewing everything as interest. All codes are eliminated. "When the flows reach the capitalist threshold of decoding and deterritorialization $(. .$.$) , it seems that there is no longer a need for a State,$ for distinct juridicial and political domination, in order to ensure appropriation, which has become directly economic" 27 . It seems that an order which does not any more assume a state is created. This thesis is but seeming. The state becomes a subject subordinated to capitalism and begins to play the role of a model of realization, i.e. implementation of axiomatics following from the functioning of the capitalist machine. It is not important either if this is a socialist, democratic or totalitarian state - it includes all of them at the same time as participants of one world market.

"From its birth capitalism has been connected with a savage repression. It very quickly acquired its organization and State apparatus. Did capitalism entail the dissolution of previous codes and powers? Absolutely. But it had already set up the gears of its power, including its State power, in the fissures of previous regimes" 28 . What is the task of the capitalist state? Participation in deterritorialization. And hence, it is standing in opposition to itself (the state is usually connected with territorialization - placement on a given land), referring to the order outside its borders, "programming" individuals based on the cosmopolitan but referring to economization of thinking (not in the sense of a small outlay but the utilitarian criteria, of profitability, Horkheimer's means and goals ${ }^{29}$ ) to realize its own interest and desires at all costs, but those desires which are products of the system (therefore, those flows that became dammed, underwent segmentation and were taken over by the state apparatus), finally to the elements connected with cultural consumption:

- uncertainty and liquidity - a need of constant movement and permanent stimuli;

- accidentality, a free view on all social relations;

27 G. Deleuze, Capitalism, [in:] C. Boundas (ed.), The Deleuze Reader, New York 1993, p. 236.

28 G. Deleuze, F. Guattari, On Capitalism and Desire, [in:] G. Deleuze, Desert Islands and Other Texts 1953-1974, Los Angeles, Cambridge, Massachusets 2004, p. 268.

29 Cf. M. Horkheimer, Krytyka instrumentalnego rozumu, Warszawa 2007. 
- a constant need to satisfy increasingly newer needs imposed and aroused by the system, so-called false needs ${ }^{30}$;

- material treatment of happiness and life, of oneself (striving at being visible and popular all the time, treating "I" as a commodity) $)^{31}$.

What, however, should appear in the place of a ruin? Decoded flows lead to a certain border after which there is only the war machine or schizophrenia. Deleuze and Guattari indicate the feedback between deterritorialization and reterritorialization. In other words, each coded distraction will be replaced by a certain compensation, if only partial. For example, deterritorialization of the codes of the territorial machine connected with local communities or primal peoples through the machine brings territorialization, e.g. in the form of a town with the walls and the border as such, even if only symbolic. Distraction from the local chiefs is supplemented by the covenant with the despot or a spiritual attachment to an abstract state, like it is the case with Urstaat. In the capitalist machine the state is supposed to be responsible for neoterritorialization. Why did Deleuze and Guattari give the prefix neo- here? An atypical situation occurs here. Building up or replacing the codes, each previous machine built on something. In this case we have to do with full decoding, deterritorialization, where nothing is left except the aforementioned economic schemes of thinking. By decoding, capitalism leads to the border after which there is schizophrenia, resistance or destruction.

It is worth giving some though to this thread. The title of Deleuze and Guattari's work is Capitalism and Schizophrenia, which with some reason points to a conjunction. A thesis is already known that capitalism is shifting its borders all the time. Firstly, it is shown in reaching the border of decoding, owing to which another axiom is required. In other words, the moment when resistance is born gets shifted through its channelization inside the system. Secondly, capitalist anti-production is spoken about here. This concept refers to two issues:

30 Cf. H. Marcuse, Człowiek jednowymiarowy. Badania nad ideologia rozwiniętego społeczeństwa przemystowego, Warszawa 1991.

31 Cf. P. Rutkowski, Homo Cōnsūmēns..., pp. 41-44. It would be extremely interesting to undertake the aspect of the relation between deterritorialization and decoding on the one hand and different cultures among many societies which differ with the axiological basis, especially where traditions point to a strong territorial attachment, the concept of nation as ethnicity or even nomadism. In societies, we can notice the elements of passing from identity of ethnical character to civic identity, which places less emphasis on the role of blood ties or common origin and more on the issues connected with being a member of a certain political community. In this there are visible elements of deterritorialization, a passage from the code oriented at the strength of territorialization to a more abstract one, connected with the state. 
- harnessing each person into the system of empowerment and subordination, into a system of power, through which the individuals inside are the object and the subject of repression of others and towards others.

- The production of goods which are not necessary, and next fabrication of the demand for them.

One aspect is still left in the hypothesis on the shifting of borders which can be called psychological. "(...) capitalism is in fact the border of each society to the extent it decodes the flows which other social formations coded or overcoded..."32. According to Deleuze and Guattari, the disease and threat to the societies produced by the capitalist machine is schizophrenia ${ }^{33}$. This is the ultimate border of capitalism beyond which there is only a war machine aiming at self-destruction or at war with the state.

\section{Diagram 2. Deterritorialization and schizophrenia}

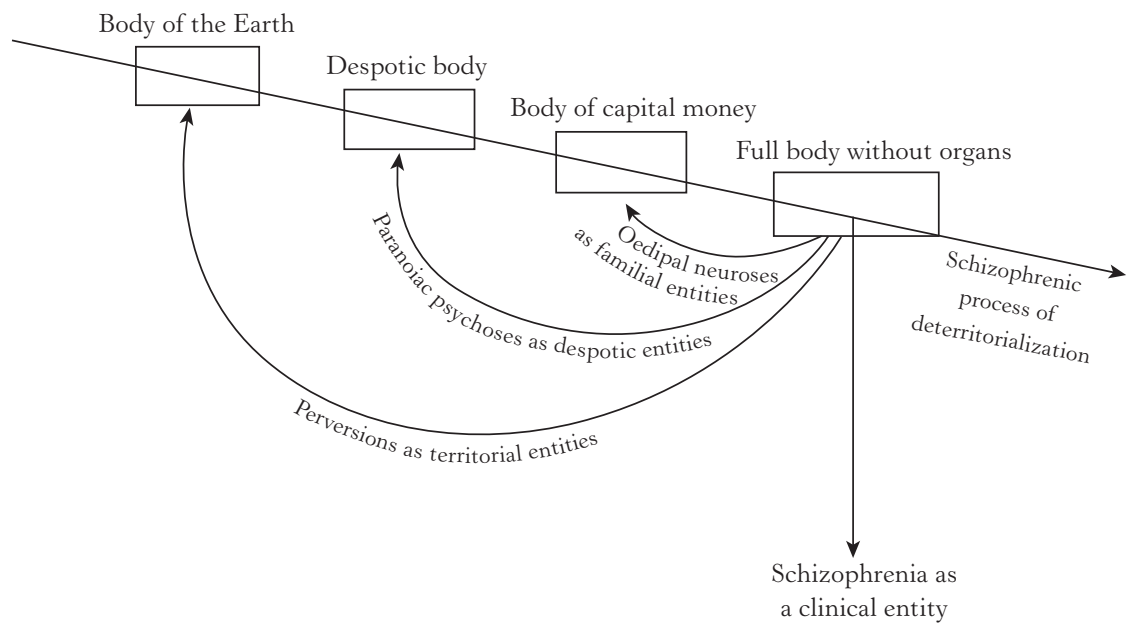

Source: G. Deleuze, F. Guattari, Anty-Edyp..., op. cit., p. 322.

Schizophrenia is an escape from the repressive, ever decoding reality which has already wreaked havoc of an individual, it is aiming at individual order. A body without organs is the one deprived of any codes. "After all, what is a schizo if not above all the one who cannot any longer

32 G. Deleuze, F. Guattari, Anty-Edyp..., p. 280.

33 Gf. G. Deleuze, F. Guattari, On Capitalism...; G. Deleuze, Schizophrenia and Society, [in:] G. Deleuze, Two Regimes... 
bear «all of this», money, stock exchange, death forces - or, as Niżyński said, values, customs, homelands, religions, private beliefs?" 34 . Hence schizoanalysis, reaching productive unconsciousness, as a psychologicaleconomic and social analysis basing on the flows of desires not subjected to segmentation, which cannot be captured by the state apparatus and by abstract machines. Decoded flows also have other ways to escape the axiomatics of capitalism. This is the war machine - the state of fully decoded flows characteristic of nomads. Then the machine can take two roads - release the lines of flight (cracks in the system) and release resistance towards the state and machines, or the road of war - in which case its only goal is to destroy an individual by itself, or a constant devastating war - this solution can only lead to fascism and micro-fascisms (which are also called a war machine inside the state which is oriented at self-destruction).

Coming back to the thread of deterritorialization, reaching the border and stopping the escape of the capitalist machine are also ensured by reterritorialization conducted by the state (what was mentioned above is worth recalling - each deterritorialization is conjugated with reterritorialization). The state as a tool serves to compensate for the aggressive, wild repression of capitalist axiomatics. Neoterritorialization takes the form of different kinds of tradition, identities or cultures, even national ones. "Those neoterritorialisms are frequently artificial, residual, archaic forms but they are archaisms of a perfectly up-to-date function; this is our modern way of «briquetting», parceling, repeated introduction of code fragments or resurrecting the old codes, inventing pseudo-codes or jargons." 35 . These are already those forms that do not possess the original codes, which have been successfully ousted, on which their authenticity was built, their territorial character has been broken with only empty forms left. Therefore, they are characterized by artificiality, which is only supposed to secure internal coherence and a lack of opposition towards changes and towards moving all references and principles onto the level of the universal, cosmopolitan world market. This is only a mechanism expected to secure relative peace inside a capitalist state and keep the flows within the frameworks comfortable for the capitalist machine.

34 G. Deleuze, F. Guattari, Anty-Edyp..., p. 385.

35 Ibidem, pp. 293-294. 


\section{Conclusions}

The perspective presented by Deleuze and Guattari nowadays rarely appears in political sciences but it is extremely interesting, different and it evades any schemes and thus it reveals reality from another point of view. In particular, because those authors present a continuation of Michel Foucault's thought, or - at least - the research of the French philosopher is the starting point for them.

The vision of state and capitalism exceeds its everyday understanding basing on the concept of decoding and deterritorialization. It could seem that such a perspective is exaggerated; however, how to call subordination of the state to the rules of the world economy and trade turnover, unification of cultures in the form of consumerist culture and McDonaldization if not decoding and deterritorialization? This approach also explains the progressing globalization, relativization and domination of economic rules of thinking.

Relations between state and capitalism in Deleuze and Guattari's thought are based on servitude and subordination. Performing the role of the model of realization is a significant aspect of the capitalist machine but this is the state's objectified role. This, however, fits the changes concerning the essence of power and state that are proceeding all the time $^{36}$. Deleuze and Guattari show that the state is not the same any more - it gave in to capital, a universalizing force and it became but an instrument of controlling people and education, decoding within the societies of control ${ }^{37}$. Culture, tradition also do not have their authenticity any more - like the state, they are but empty forms and artificial elements of repression.

Is a way out of this situation, a way towards freedom possible? According to Deleuze and Guattari, liberation should be based on desire, flows - those forces which can free man from repression and direct themselves against machines and the state. As mentioned before, this struggle is not, however, easy. It can lead to destruction. Another challenge facing

36 Cf. A. Rothert, Państwo postsuwerenne, «Studia Politologiczne» 2010, Vol. 17; B. Kaczmarek, Polityka a władza. Kryzys Paradygmatu?, «Studia Politologiczne» 2004, Vol. 8; P. Rutkowski, Podmiotowość państwa we wspótczesnym świecie. Globalizacja a sterowność, «Idea. Studia nad strukturą i rozwojem pojęć filozoficznych» 2018, No. 2; A. Toffler, Zmiana wtadzy: wiedza, bogactwo, przemoc u progu XXI stulecia, Poznań 2003; P. Borowiec, Wymuszona dekonstrukcja - Lewiatan w uścisku procesu globalizacji, [in:] P. Borowiec, B. Krauz-Mozer (eds.), Globalizacja - nieznośne podobieństwo, Kraków 2008.

37 G. Deleuze, Postscript on the Societies of Control, «October» 1992, Vol. 59. 
contemporary times is maintaining the line of flight and flows in critical and not suicidal forms.

Originality and aptness, convincing arguments and sharpness of reflections make rhizomatics and nomadology proposed by Deleuze and Guattari worth considering as an interesting perspective to study social phenomena. Against the human need to put the world in order, this is essentially what reality is like - indefinite, complicated, full of blurred processes and entities. This is also what capitalism is like in its relations with the state.

\section{Bibliography}

Borowiec P., Wymuszona dekonstrukcja - Lewiatan w uścisku procesu globalizacji, [in:] P. Borowiec, B. Krauz-Mozer (eds.), Globalizacja - nieznośne podobieństwo, Kraków 2008.

Dahl R., Stinebrickner B., Wspótczesna analiza polityczna, Warszawa 2007.

Deleuze G., Capitalism, [in:] C. Boundas (ed.), The Deleuze Reader, New York 1993.

Deleuze G., What is a Dispositif, [in:] G. Deleuze, Two Regimes of Madness. Texts and Interviews 1975-1995, Massachusets 2006.

Deleuze G., Many Politics, [in:] G. Deleuze, Dialogues, New York 1997.

Deleuze G., Michel Foucault's Main Concepts, [in:] G. Deleuze, Two Regimes of Madness. Texts and Interviews 1975-1995, Massachusets 2006.

Deleuze G., Postscript on the Societies of Control, «October» 1992, Vol. 59.

Deleuze G., Guattari F., Anty-Edyp. Kapitalizm i schizofrenia, Warszawa 2017.

Deleuze G., Guattari F., On Capitalism and Desire, [in:] G. Deleuze, Desert Islands and Other Texts 1953-1974, Los Angeles, Cambridge, Massachusets 2004.

Deleuze G., Guattari F., Tysiac Plateau, Warszawa 2015.

Foucault M., Archeologia wiedzy, Warszawa 1977.

Foucault M., Historia seksualności, Warszawa 1995.

Foucault M., On Power, [in:] M. Foucault, Politics, Philosophy, Culture and Other Writings, New York 1990.

Foucault M., Nadzorować i karać. Narodziny więzienia, Warszawa 1998.

Heidegger M., Bycie i czas, Warszawa 2013.

Horkheimer M., Krytyka instrumentalnego rozumu, Warszawa 2007.

Kaczmarek B., Organizacje: polityka, władza, struktury, Warszawa 2001.

Kaczmarek B., Polityka a władza. Kryzys paradygmatu?, «Studia Politologiczne» 2004, Vol. 8.

Marcuse H., Człowiek jednowymiarowy. Badania nad ideologia rozwiniętego społeczeństwa przemystowego, Warszawa 1991.

Nowicka M., 'Urzadzenie', 'zastosowanie', 'układ' - kategoria dispositif u Michela Foucaulta, jej ttumaczenia $i$ ich implikacje dla postfoucaultowskich analiz władzy, «Przegląd Socjologii Jakościowej» 2011, No. 2.

Rothert A., Państwo postsuwerenne, «Studia Politologiczne» 2010, Vol. 17.

Rutkowski P., Bernard Stiegler, Taking Care of Youths and the Generations, [in:] P. Rutkowski, J. Ziółkowski (eds.), Oblicza przemocy, Warszawa 2019.

Rutkowski P., Hermeneutyka filozoficzna wobec wybranych problemów metateoretycznych, [in:] F. Pierzchalski, M. Tobiasz, J. Ziółkowski (eds.), Podmiot-kultura-socjotechnika. Wokót 
holistycznej interpretacji polityki. Ksiega jubileuszowa dedykowana profesorowi zw. dr. hab. Mirosławowi Karwatowi, Warszawa 2020.

Rutkowski P., Homo Cōnsūmēns. Kulturowy model człowieka w epoce zglobalizowanego kapitalizmu kognitywnego, «Annales Universitatis Paedagogicae Cracoviensis. Studia Politologica» 2019, No. 22.

Rutkowski P., Podmiotowość państwa we wspótczesnym świecie. Globalizacja a sterowność, «Idea. Studia nad strukturą i rozwojem pojęć filozoficznych» 2018, No. 2.

Sasińska-Klas T., Socjalizacja polityczna. Teorie, badania, ustalenia, Kraków 1992.

Scott J., Władza, Warszawa 2006.

Stiegler B., Taking Care of Youth and the Generations, Stanford 2010.

Szacki J., Historia myśli socjologicznej, Warszawa 2002.

Szahaj A., Teoria krytyczna szkoly frankfurckiej. Wprowadzenie, Warszawa 2008.

Teichert D., Hermeneutics: Polity, Politics, and Political Theory in Gadamer's Philosophical Hermeneutics, «Teoria Polityki» 2020, No. 4.

Toffler A., Zmiana wtadzy: wiedza, bogactwo, przemoc u progu XXI stulecia, Poznań 2003. 